\title{
TOXOPLASMA GONDII INFECTION IN RATS BY THE RH STRAIN: INOCULUM AND AGE EFFECTS
}

\author{
DE CHAMPS C.*, PELLOUX H.**, DECHELOTTE P.***, GIRAUD J.C.*, \\ BALLY N.* \& AMBROISE-THOMAS P.**
}

Summary :

Toxoplasma gondii strains are classified according to their virulence in mice. Rats are considered to be resistant to the infection, depending on the age. Newborn rats are fully susceptible but weaned rats are resistant. However the effect of inoculum has not been examined. Using $\mathrm{RH}$ strain inocula of $10^{2}$, $10^{4}, 5 \times 10^{7}$ and $10^{8}$ tachyzoites intraperitoneally inoculated into Wistar and Fischer rats of 7, 11, 21, 24 and 46 days old, the authors show that inoculum and not the age of the host had a statistically significant effect $(p<0.01)$ on the survival curve.

KEY WORDS : Toxoplasma gondii, RH strain, virulence, rat, liver lesion.
Résumé : INFECTION DU RAT PAR LA SOUCHE RH DE TOXOPLASMA GONDII : ROLE DE L'EFFET INOCULUM

Les souches de Toxoplasma gondii sont classées en fonction de leur virulence pour la souris. On considère que la résistance du rat à l'infection est habituellement liée à l'âge. Les rats nouveau-nés sont très sensibles mais après le sevrage les rats sont résistants. En utilisant la souche $\mathrm{RH}$ à des inoculums de $10^{2}, 10^{4}, 5 \times 10^{7}$ et $10^{8}$ tachyzoiltes par voie intrapéritonéale à des rats Fischer et Wistar âgés de 7, 11, 21, 24 et 46 jours, les auteurs montrent que l'importance de l'inoculum a un effet statistiquement significatif sur la survie $(p<0,01)$ alors que celui de l'âge à l'inoculation n'en a pas.

MOTS CLÉS : Toxoplasma gondii, souche RH, virulence, rats, lésions hépatiques

\section{INTRODUCTION}

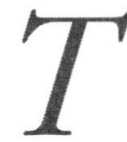
oxoplasma gondii strains are classified as virulent or non-virulent based on infectivity in mice. The RH strain of $T$. gondii is the most virulent strain for mice. It was isolated from the brain of a six-year old child (Sabin, 1941). Genetically, it is one of the type I strains (Howe \& Sibley, 1995) which are extremely virulent in mice; one infective tachyzoite is lethal to mice (Dubey, 1998). Virulence of types II and III strains of $T$. gondii is variable (Howe \& Sibley, 1995). Rats are considered to be one of the most resistant hosts for RH strain $T$. gondii but opinions differ with respect to age of resistance acquisition, lethal dose, and formation of tissue cysts (Lainson, 1955; Lewis \& Markell, 1958; Kulasiri, 1962; De Meuter, 1972; Chinchilla et al., 1981; Dubey \& Frenkel, 1998). There is general agreement, except for the conflicting report of Remington et al. (1958), that natural resis-

\footnotetext{
* Laboratoire de Parasitologie, Faculté de Médecine, 28, place Henri Dunant, F-63001 Clermont-Ferrand.

** DP3M, RHAP, UPRES-A CNRS 50-82, Faculté de Médecine, F-38043 Grenoble Cedex 9.

*** Service d'Anatomie Pathologique, Hôtel Dieu, BP 69, F-63003 Clermont-Ferrand Cedex.

Correspondence : Dr Hervé Pelloux - Tél. : 0476765490 - Fax : 0476765660 .
}

tance starts at an early age and that inoculums $<10^{7}$ do not kill the animal. The aim of this study was to determine the effect of dose on morbidity and mortality in rats inoculated intraperitoneally (i.p.) with $\mathrm{RH}$ strain.

\section{MATERIAL AND METHODS}

T achyzoites of the RH strain of $T$. gondii were obtained from mouse peritoneal fluid three days after i.p. inoculation and washed twice in physiological saline $(0.85 \% \mathrm{NaCl})$. The strain was subinoculated twice weekly into Swiss OF1 mice (IFFACREDO, L'Arbresle, France) in our laboratory.

In total 30 rats were used in the present study (Table I). 24 male and female Wistar rats from three litters were assigned to 12 pairs. Three different pairs were i.p. inoculated at the age of 7, 11, 24 and 46 days with either $10^{2}, 10^{4}$ or $10^{8}$ tachyzoites of the T. gondii RH strain (De Champs et al., 1997). In each pair, one was killed two weeks and the other four weeks after inoculation by barbiturate overdose. They were weighed at the time of inoculation and at sacrifice.

A quarter of each rat brain was homogenized in $1 \mathrm{ml}$ of phosphate buffer saline (PBS) and $500 \mu \mathrm{l}$ inoculated into a Swiss mouse and another quarter was used for histological examination. The remaining half was 


\begin{tabular}{|c|c|c|c|c|c|}
\hline \multirow[b]{2}{*}{$\begin{array}{c}\text { Age } \\
\text { (days) }\end{array}$} & \multicolumn{4}{|c|}{$\begin{array}{l}\text { No of dead rats/ } \\
\text { No of rats injected with } \\
\text { stated number of tachyzoites }\end{array}$} & \multirow[t]{2}{*}{$\begin{array}{l}\text { No of dead rats } \\
/ \text { No of } \\
\text { rats injected }\end{array}$} \\
\hline & $10^{2}$ & $10^{4}$ & $5.10^{7 *}$ & $10^{8}$ & \\
\hline 7 & $0 / 2$ & $1 / 2$ & 0 & $2 / 2$ & $3 / 6$ \\
\hline 11 & $0 / 2$ & $0 / 2$ & 0 & $2 / 2$ & $2 / 6$ \\
\hline 21 & $0 / 0$ & $0 / 0$ & $1 / 2$ & $0 / 0$ & $1 / 2$ \\
\hline 24 & $0 / 2$ & $0 / 2$ & 0 & $2 / 2$ & $2 / 6$ \\
\hline 46 & $0 / 2$ & $0 / 2$ & $1 / 4$ & $0 / 2$ & $1 / 10$ \\
\hline $\begin{array}{l}\text { No of dead rats/ } \\
\text { No of rats injected }\end{array}$ & d $0 / 8$ & $1 / 8$ & $2 / 6$ & $6 / 8$ & $9 / 30$ \\
\hline
\end{tabular}

* The 6 rats inoculated with $5.10^{7}$ tachyzoites were Fischer rats, all others were Wistar rats.

Table I. - Mortality in rats in relation to age and the number of tachyzoites of $T$. gondii inoculated.

homogenized in PBS in a Potter's tube, purified by centrifugation on a discontinuous density gradient of $30 \%$ and $90 \%$ Percoll (Blewett et al., 1983) and examined for the presence of tissue cysts. For seven of the rats inoculated at 24 and 46 days, histological sections of the liver were also examined.

Six male Fischer rats were inoculated i.p. with $5 \times 10^{7}$ tachyzoites, two at the age of 21 days and four at 46 days. They were weighed during the first 10 days and killed seven months later. The brain was homogenized in $2 \mathrm{ml}$ PBS in a Potter's tube and purified in Percoll gradient. All the rats were fed ad libitum.

Weights of the rats inoculated after 11 days were expressed in standard deviation (SD) according to the mean weight for the age, using the growth curve for the species given by IFFA CREDO. Weight losses were calculated by substracting from the weight (in SD) at inoculation, the weight (in SD) at the 10th, 15th or 30th days, according to the date of sacrifice. They were compared according to inoculum or age at inoculation by the Krushall-Wallis rank-test (Woolson, 1987).

Spleen, liver, heart, lungs and brain were processed for histological examination from three of the rats that died of acute toxoplasmosis. Paraffin-embedded sections were cut at $5 \mu \mathrm{m}$ and sections were stained with Giemsa, periodic acid Schiff (PAS), hematoxylin-eosinsaffron (HES) and indirect immunofluorescent assay (IFA) (Derouin et al., 1989).

After paraffin removal and rehydration, the sections were incubated for $30 \mathrm{~min}$ at $37^{\circ} \mathrm{C}$ with a rabbit polyclonal anti- $T$. gondii hyperimmune serum diluted $1 / 300$ in PBS. After washes in PBS they were treated with anti-rabbit IgG conjugate (Sanofi Diagnostic Pasteur, Marnes la Coquette, France) at 1/100 dilution in PBS. The specimens were observed by epifluorescence microscopy. The survival curves were compared using the Mantel-Haenzel test (Woolson, 1987).

\section{RESULTS}

T he mortality rate according to age and inoculum are summarized in Table I. All deaths occurred within the first eight days after inoculation. No rat died after inoculation with $10^{2}$ tachyzoites. The rat that died after an inoculation with $10^{4}$ tachyzoites was seven days old when inoculated. The statistical analysis of the survival curve showed a significant difference for the inoculum $(p<0.01)$ but not for age.

Among the surviving rats, one rat inoculated with $10^{2}$ tachyzoites at seven days lost its hair. With the inoculum $\geq 10^{4}$ a delay in growth was observed, and with $5.10^{7}$ and $10^{8}$ the rats lost almost three standard deviations in weight (Table II).

On histological examination, the rats that died during the acute infection had no lesions in the lungs or spleen. In the liver, the Glisson capsule was thicker and infiltrated by lymphocyte cells and numerous tachyzoites were seen. Tachyzoites were observed in the brain of two rats, and inflammatory lesions in their heart were associated with tachyzoites-shaped organisms. A total amount of $10^{2}$ to $10^{6}$ tachyzoites was harvested from the ascites.

Tissue cysts were observed in the homogenate brain of nine killed rats (Table III) and none at the histological examination of the brain or the liver (De Champs et al., 1997). Eleven of the 17 mice inoculated i.p. with the brain of these rats died.

\begin{tabular}{lcccc}
\hline Inoculum & $\begin{array}{c}10^{2} \\
(\mathrm{n}=4)^{* *}\end{array}$ & $\begin{array}{c}10^{4} \\
(\mathrm{n}=4)\end{array}$ & $\begin{array}{c}5.10^{7} \\
(\mathrm{n}=4)\end{array}$ & $\begin{array}{c}10^{8} \\
(\mathrm{n}=2)\end{array}$ \\
\hline $\begin{array}{l}\text { Standard } \\
\text { deviation } \\
\text { (mean) }\end{array}$ & +0.1 & -1.9 & -2.8 & -2.8 \\
\hline
\end{tabular}

* Difference between the standard deviation at inoculation and 15 or 30 days after inoculation, according to the growth curves of the species given by IFFA CREDO.

** Number of surviving rats inoculated after 11 days.

Table II. - Weight growth delay *.

\begin{tabular}{cccc}
\hline $\begin{array}{c}\text { Day } \\
\text { rat } \\
\text { was killed }\end{array}$ & $\begin{array}{c}\text { No } \\
\text { of rats } \\
\text { killed }\end{array}$ & $\begin{array}{c}\text { No of rats } \\
\text { with tissue cyst } \\
\text { in brain homogenate }\end{array}$ & $\begin{array}{c}\text { No of } T \text {. gondii } \\
\text { infected rats* }\end{array}$ \\
\hline 15 & 9 & 3 & 6 \\
30 & 8 & 6 & 5 \\
$207-230$ & 4 & 0 & 2 \\
\hline
\end{tabular}

* By bioassay in mice inoculated i.p. with rat brains.

Table III. - Persistence of RH strain in brains of rats according to the date of kill. 
No tissue cyst was observed in the homogenate brain of the four rats inoculated with $5.10^{7}$ tachyzoites and killed seven months later. The mice subinoculated with the brain of two rats survived, and those inoculated with the brain of two other rats died 87 and 130 days later. T. gondii were observed in ascites from one of the mice. The proportion of mice that died after i.p. subinoculation with the brain of rats decreased when the rats were killed later and when the rats were older at inoculation (Table IV). The association between the age of rats at inoculation and the number of subinoculated mice that died was statistically significant $(p<0.01)$.

\begin{tabular}{cccc}
\hline $\begin{array}{c}\text { Age } \\
\text { at injection } \\
\text { (days) }\end{array}$ & $\begin{array}{c}\text { No of rats } \\
\text { killed }\end{array}$ & $\begin{array}{c}\text { No of rats with tissue } \\
\text { cyst in brain } \\
\text { homogenate }\end{array}$ & $\begin{array}{c}\text { No of } \\
\text { infected rats* }\end{array}$ \\
\hline 7 & 3 & 1 & 2 \\
11 & 4 & 3 & 4 \\
21 & 1 & 0 & 1 \\
24 & 4 & 2 & 4 \\
46 & 9 & 3 & 2 \\
\hline
\end{tabular}

* By bioassay in mice inoculated i.p. with rat brains.

Table IV. - Persistence of RH strain T. gonidii in brains of rats according to the date at inoculation.

\section{DISCUSSION}

1 he results of this study show that the resistance of rats to infection by the RH strain is only partially age-dependent and that large inocula can be lethal for adult animals. These results agree with those obtained with RH strain (Remington et al., 1958) and with VEG strain oocysts (Dubey, 1996) in SpragueDawley rats. Our findings do not support the hypothesis that weaned rats are resistant and that resistance is acquired at an early age (Lainson, 1955; De Meuter, 1972; Chinchilla et al., 1981).

The lethal dose of $T$. gondii for rats varies with age of the rat. De Meuter (1972) observed $88 \%(22 / 25)$ mortality in one day old rats inoculated with $10^{5}$ tachyzoites and Remington et al. (1958) found 33 to $50 \%$ mortality in Sprague-Dawley rats weighing $120 \mathrm{~g}$ (then probably about five week old) inoculated with $10^{8}$ tachyzoites. From these studies it is concluded that three rat species, Wistar, Fischer and Sprague-Dawley, have similar resistance to $\mathrm{RH}$ strain and that lethal dose of tachyzoites is $>10^{7}$ for adult rats and $10^{4}$ for younger rats.

There is little documented evidence on clinical disease in rats. Toxoplasmosis in rats had been considered asymptomatic (Frenkel, 1956; Lewis \& Markell, 1958).
In our studies infection with inoculum $\leq 10^{7}$ tachyzoites was followed by growth delay.

Dubey (1996) showed that the number of tissue cysts observed in tissue sections was significantly lower than in brain homogenates. This could explain why no tissue cyst was found in the histological sections of our study because very few tissue cysts were obtained in the brain homogenates. However, subinoculation of rat brains into mice indicated that rats were infected with T. gondii. The persistence of the $\mathrm{RH}$ strain in rats is variable and depends on the infecting dose (Pettersen, 1988). In our study, the survival of the i.p. subinoculated mice was more closely related to the age of the rats at infection than to the date of the kill. But the absence of early fatal toxoplasmosis among the mice subinoculated with the brain of rats killed after 200 days post-infection suggests that the stage or the virulence of the RH strain in these rats is not the same as during the first month post-infection.

\section{ACKNOWLEDGEMENTS}

We thank Dr J.P. Dubey for his help in revising the manuscript.

\section{REFERENCES}

Blewett D.A., Miller J.K. \& Harding J. A simple technique for direct isolation of Toxoplasma tissue cysts from foetal brain. Veterinary Record 1983, 112, 98-100.

Chinchilla M., Alfaro M. \& Guerrero O.M. Adaptacion natural de rata blanca a Toxoplasma gondii. Revista de Biologia Tropical 1981, 29, 273-282.

De Champs C., Imbert-Bernard C., Belmeguenai A., Ricard J., Pelloux H., Brambilla E. \& Ambroise-Thomas P. Toxoplasma gondii: In vivo and in vitro cystogenesis of the virulent RH strain. Joumal of Parasitology, 1997, 83, 152155 .

De MeuTER F. Sensibilité du rat nouveau-né à certaine souches de Toxoplasma gondii isolées chez l'homme. Médecine et Maladies Infectieuses, 1972, 2-10, 345-346.

Derouin F., Sarfati B., Beauvais B., ilion M.C. \& DEHEN L. Laboratory diagnosis of pulmonary toxoplasmosis in patient with acquired immunodeficiency syndrome. Journal of Clinical Microbiology, 1989, 27, 1661-1663.

DuBEY J.P. Pathogenicity and infectivity of Toxoplasma gondii oocysts for rats. Journal of Parasitology, 1996, 82, 951-956.

DUBEY J.P. Re-examination of resistance of Toxoplasma gondii tachyzoites and bradyzoites to pepsine and trypsin digestion. Parasitology, 1998, 116, 4 -50.

Dubey J.P. \& Frenkel J.K. Toxoplasmosis of rats: a review, with considerations of their value as an animal model and their possible role in epidemiology. Veterinary Parasito$\log y, 1998$ (in press). 
FRENKEL J.K. Pathogenesis of toxoplasmosis and of infections with organisms resembling Toxoplasma. Annals of New York Academy of Sciences, 1956, 64, 215-251.

HOWE D. K. \& SIBLEY D. Toxoplasma gondii comprises three clonal lineages: correlation of parasite genotype with human disease. The Journal of Infectious Diseases, 1995, 172, 1561-1566.

KULASIRI C. The behaviour of suckling rats to oral and intraperitoneal infection with a virulent strain of Toxoplasma gondii. Parasitology, 1962, 52, 193-198.

LAINSON R. Toxoplasmosis in England II. Variation factors in the pathogenesis of Toxoplasma infections : the sudden increase of virulence of a strain after passage in multimammate rats and canaries. Annals of Tropical Medicine and Parasitology, 1955, 49, 397-429.

LEWIS W.P. \& MARKELL E.K. Acquisition of immunity to toxoplasmosis by the newborn rat. Experimental parasitology 1958, 7, 463-467.

PeTtERSEN E.K. Resistance to avirulent Toxoplasma gondii in normal and vaccinated rats. Acta Pathologica Microbiologica Immunologica Scandinavica 1988, 96, 820-824.

Remington J.S., JaCOB L. \& Kaufman H.E. The relation of infective dose to residual infection and to the possibility of congenital transmission. American Journal of Ophtalmology, 1958, 46, 261-268.

SABIN A.B. Toxoplasmic encephalitis in children. Journal of American Medical Association, 1941, 116, 801-807.

WoOlson R.F. Statistical methods for the analysis of biomedical data. Wiley J. E Sons (eds) New York. 1987, 366-369, 418-424 and 453-455.

Reçu le 24 octobre 1997 Accepté le 15 février 1998 